\title{
Emphasizing Inter-Nation Equity in the New Digital Economy's Taxing Rights Allocation Scheme
}

\author{
Arief Hakim P. Lubis*, Ning Rahayu* \\ * Faculty of Administrative Sciences, Universitas Indonesia \\ DOI: 10.29322/IJSRP.11.07.2021.p11553 \\ http://dx.doi.org/10.29322/IJSRP.11.07.2021.p11553
}

\begin{abstract}
Efforts to quell the challenges of taxing the digital economy have shown significant progress. The phase has narrowed down to agreeing on broader allocation of taxing rights to market jurisdictions. However, various groups still have differing views regarding the scheme of new taxing rights allocation (Amount A) contained in the proposal OECD/G20 Pillar One. The issue of fairness mounts mainly in the formula for reallocating profits to the eligible jurisdictions. This study aims to examine areas in the proposal related to the principle of inter-nation equity. We apply a qualitative study by conducting literature analysis and document review. The result shows that several areas need to improve inter-nation equity, particularly in the mechanism for reallocating MNE group profits to jurisdictions entitled to Amount A. We identify the stages in the mechanism where the principle of equity amidst countries becomes essential as a point of consideration. These are residual profit terms, profitability threshold, and the percentage of reallocation. Consensus needs to consider the favored percentage formula to improve inter-nation equity before the scheme is fully implemented.
\end{abstract}

Index Terms- Digital Economy, Inter-nation Equity, International Taxation, OECD/G20 Pillar One, New Taxing Rights

\section{INTRODUCTION}

$\mathrm{D}$ iscussions about the taxation challenges of the digital economy have escalated to the issue of sharing taxing rights interjurisdictions. As is well known amidst the public, the digital economy, on the one hand, has succeeded in driving economic growth and supporting the opening of new job opportunities ( $\mathrm{Li}$ et al., 2020), but on the other hand, it allows challenges for international taxation (OECD, 2013). The main challenges arise regarding multinational enterprises (MNE) that smooth to operate across jurisdictions and have a significant digital presence in a country's economy yet hard to tax. This could be due to the lack of nexus under the current international taxation framework (OECD, 2015).

Over recent decades, the digital economy is growing rapidly and dynamically in line with technology penetration in various forms of human activity (Tambunan and Rosdiana, 2020). The spread of the digital economy has made the value of this sector mount significantly. However, this enormous economic potential is not accompanied by the realization of taxes collected from giant digital economy players such as Google, Facebook, and Amazon in market jurisdictions (Schoen, 2017). Tax authorities worldwide know the magnitude of the profits generated by the digital business players, but challenging to impose a tax on such profits (Jones et al., 2018).

This situation makes the global community give impetus to reform the international taxation framework. International tax rules deemed incapable of longer offsets the changes in the business world, particularly in the era of digital growth (Li, 2015). The pressure to attempt a global solution to impose digital tax increased amid urgent funding needs for economic recovery due to the pandemic covid-19 (Alm et al., 2020).

As a response to addressing the challenges of taxing the digital economy, the OECD met with the G20 and formed several strategic actions. The problems of taxing the digital economy identified are increasingly widespread, and the quest for consensus involves more states through the Inclusive Framework (OECD, 2018). The phase has narrowed down to agreeing on broader distribution of taxing rights to market jurisdictions. The distribution scheme is contained in the Amount A element of the OECD/G20 BEPS Pillar One proposal.

The new taxing rights allocation scheme (Amount A) applies several stages and filtration to determine the eligible jurisdictions and the measure of profit to be allocated (OECD, 2020). The allocation formula will ultimately provide a share of the residual profit of the MNE group to jurisdictions that meet the terms according to the Amount A provisions. However, this scheme then escalates a difference of opinion among the jurisdictions involved. Issues then come to the surface regarding this proposal's capability to provide a fair share of the profits on the revenue generated in the market jurisdictions (Cobham et al., 2019). 
Based on the problems, this study aims to examine the principles of equity in the Amount A draft contained in the OECD/G20 Pillar One proposal. The study will focus on the dimensions of inter-nation equity. The structure of this article is as follows. The following section will discuss the conceptual framework as the theoretical base used in this study. After that, the paper will expose the research methods used. Finally, a discussion and review of analysis results will be served in the segment prior to the conclusion as a closing.

\section{CONCEPTUAL FRAMEWORK}

\section{A. The Concept of the Digital Economy and Its Expansion}

The concept of the digital economy was initially introduced in 1995 by a Canadian expert who is also a business strategist named Don Tapscott. In his book entitled The Digital Economy: Promise and Peril in the Age of Networked Intelligence, Tapscott (1995) defines the digital economy as economics in the era of network intelligence, which is a new economy in which all forms of information become entirely digital, reduced to bits across the network and stored on the computer.

The availability of global internet connectivity and significant technological advances have resulted in rapid digital economic growth over the last two decades (Sukardi et al., 2020). However, according to Turina (2020), the digital economy is not just one part of the economic sector but involves the entire economy itself. Furthermore, the digital economy results from the transformation process brought about by Information and Communication Technology (ICT), so it needs to be understood as a spectrum, not as a specific business field. Thus, the digital economy applies to all businesses, both within the scope of traditional businesses and new business models that employ tools and operate in the digital space.

The rapid development of the digital economy has made the value of the sector expanding significantly. Research by Oxford Economics and Huawei (2017) estimates that the value of the digital economy globally reached over USD 11.5 trillion in 2016. This is equivalent to $15.5 \%$ of the world's Gross Domestic Product (GDP). Furthermore, the scale of this digital economy will continue to multiply where the same study results show its growth is 2.5 times faster than world GDP over the last 15 years.

The growth of the digital economy has an impact on various aspects of life. The increase in digitalization has made a significant contribution to the 21st century and brought drastic changes in routine (Geringer, 2021). Economic digitalization in the form of advances in Information and Communication Technology (ICT) has changed business dynamics, increased productivity, and expanded industry in many countries (Yuan et al., 2021).

Businesses in the digital economy have some mechanism in changing the value into revenue. The table below illustrates the five main revenue models in the digital economy.

Table 1. Revenue Model of the digital economy

\begin{tabular}{|c|c|c|c|}
\hline No & Type of Income & Source of Income & Description \\
\hline 1 & $\begin{array}{l}\text { Revenue from online } \\
\text { advertising services }\end{array}$ & $\begin{array}{l}\text { - Online Advertising Services } \\
\text { - Online Search Engines } \\
\text { - Social Media Platforms } \\
\text { - Online Intermediation Platform Services } \\
\text { - Digital Content Services } \\
\text { - Online Gaming } \\
\text { - Standardized Online Teaching Services } \\
\text { - Cloud Computing Services }\end{array}$ & $\begin{array}{l}\text { Earning revenue from online } \\
\text { advertising services, primarily } \\
\text { from fees paid by advertisers. Ads } \\
\text { viewed or clicked on. MNEs earn } \\
\text { revenue based on views, clicks, or } \\
\text { a combination of both. }\end{array}$ \\
\hline 2 & $\begin{array}{l}\text { Revenue from sales or other } \\
\text { collection of user data }\end{array}$ & $\begin{array}{l}\text { - Sale or Other Alienation of User Data } \\
\text { - Online Search Engines } \\
\text { - Social Media Platforms } \\
\text { - Online Intermediation Platform Services } \\
\text { - Digital Content Services } \\
\text { - Online Gaming } \\
\text { - Standardised Online Teaching Services }\end{array}$ & $\begin{array}{l}\text { Earning revenue by monetizing } \\
\text { personal data available online. } \\
\text { The data is typically sold to } \\
\text { companies for campaigns } \\
\text { targeting the most relevant users. }\end{array}$ \\
\hline 3 & $\begin{array}{l}\text { Revenue from digital content } \\
\text { services }\end{array}$ & $\begin{array}{l}\text { - Social Media Platforms } \\
\text { - Online Intermediation Platform Services } \\
\text { - Digital Content Services } \\
\text { - Online Gaming } \\
\text { - Standardised Online Teaching Services }\end{array}$ & $\begin{array}{l}\text { Earning revenue from users who } \\
\text { purchase digital content per } \\
\text { download item - for example, e- } \\
\text { books, videos, apps, games, and } \\
\text { music. }\end{array}$ \\
\hline 4 & $\begin{array}{l}\text { Revenues from online services } \\
\text { intermediary platform }\end{array}$ & - Online Intermediation Platform Services & $\begin{array}{lrr}\text { Earning } & \text { revenue } & \text { from } \\
\text { commissions } & / & \text { intermediation } \\
\text { service fees } & & \\
\end{array}$ \\
\hline
\end{tabular}




\begin{tabular}{|l|l|l|l|}
\hline No & \multicolumn{1}{|c|}{ Type of Income } & \multicolumn{1}{c|}{ Source of Income } & \multicolumn{1}{c|}{ Description } \\
\hline 5 & $\begin{array}{l}\text { Revenue from cloud } \\
\text { computing services }\end{array}$ & - Cloud Computing Services & $\begin{array}{l}\text { Earning revenue from providing } \\
\text { extensive professional document } \\
\text { management and storage services, } \\
\text { providing computing power to } \\
\text { other businesses, hosting } \\
\text { websites, and providing software } \\
\text { for data from highly specialized } \\
\text { operating engines such as aircraft. }\end{array}$ \\
\hline
\end{tabular}

Source: Modified by authors from OECD (2015) and OECD (2020)

\section{B. Concept of International Taxation Framework}

The development of the digital economy also raises challenges and consequences in the sphere of taxation. There are two main issues with taxing digital corporate income by source jurisdictions. First, a business model with digitalization generates enormous profits from consumers without the need for a physical presence in their jurisdiction (Jones et al., 2018). Second, the use of electronic data and intangible assets provides opportunities for digital businesses to shift profits more aggressively (Olbert and Spengel, 2019).

The main challenge of taxing the digital economy emerges for foreign companies operating across jurisdictions. To impose taxes on non-resident business entities, the authorities must consider the Tax Treaty provisions between countries. Under the arm's length principle, income earned by foreign companies from business activities carried out in the source country only taxable if there is a Permanent Establishment (PE) in such jurisdiction (Kobetsky, 2011).

Vann (1998) describes PE as attribution of income refers to the company's presence in a country either through the office or personnel. Therefore, jurisdictions may tax business income solely if the profits are associated with the presence of PE (Rohatgi, 2007). Meanwhile, the digitalization of the economy has made it easier for goods and services to be delivered to customers worldwide without establishing a PE or subsidiaries in the jurisdiction (Schoen, 2017).

In the digital economy era, cross-border transactions are common. Each country has the right to tax the income derived from such cross-border transactions. Kobetsky (2011) defines tax jurisdiction as the state's authority to impose levies that individuals and corporations pay. The tax jurisdiction of a country is based on (1) taxation of residents, including individuals and corporations, regarding their worldwide income, and (2) taxation of non-residents on income originating from the territory of their country (Kobetsky, 2011).

The expansion of the digital economy has also raised the debate about the current mechanism for allocating taxing rights, both in developed economies, particularly toward developing economies (Devereux et al., 2021). The current taxing rights allocation scheme does not allow market jurisdictions to get a fair share of taxes on the profits earned by the 'giant' digital businesses. On the other hand, some countries affirm that domestic users of digital services make a considerable contribution to the profits of digital businesses, so that some taxing rights should be given to the country where the users are located (Devereux et al., 2021).

\section{The Concept of Fairness in Tax Policy}

In its simplest form, tax policy intends to achieve fairness (Pistone et al., 2019). Therefore, in a good tax policy principle, equity is one of the "building blocks" that must exist when designing a tax policy. Pistons et al. (2019) details the equity factor into four indicators, i.e., horizontal equity (equal treatment for the equals), vertical equity (unequal treatment for the unequal), legitimacy (the existence of a nexus connecting subject/object with jurisdiction) and inter-nation equity (distribution of taxing rights between countries).

Based on the principle of equity, the design and construction of a tax policy and regulation should be based on the intention of fulfilling fairness. In line with the taxpayer's perspective, the principle of equity also needs to be considered from the inter-nation side, entitled inter-nation equity (Pistone et al., 2019). When designing the distribution of taxing rights in the digital economy, the points of inter-nation equity are primary indicator that needs to be considered (Schoen, 2019). At a certain level, inter-nation equity has received little attention, particularly regarding the concept of vertical equity between countries to encourage progress in the distribution of taxing rights between developed and developing economies. The distribution of taxing rights requires the existence of nexus.

Tax authorities need to consider several strategies to face taxation challenges in the digital economy, including the tax base, the tax rate policies, and the scheme for taxing the digital economy's income from cross-border transactions through the source jurisdiction. Tax policy is not only confined to raising revenue, but it is essential to achieve the aspect of equity. This is in line with Devereux (1996) as follows:

"Tax policy is not just about encouraging good things and discouraging bad things. Nor is it just about rising the required revenue with the minimum amount of distortion to economic activity, and with the minimum cost of collection. It is also about fairness". 
Traditionally, "fairness" is primarily concerned with applying the "benefit principle" to legitimize tax collection in the source jurisdiction. This argument starts from the common assumption that all taxpayers must contribute taxes to public funds consider the benefits received (Pistone et al., 2019). Although generally accepted, this concept proves to be tricky to apply when designing the allocation of taxing rights between the different jurisdictions. This situation becomes even more complicated in the data and information technology-driven economic sector (Schoen, 2019).

\section{RESEARCH METHOD}

This study applied qualitative research methods. The method provides a comprehensive overview of the phenomena discussed. Study with qualitative methods relies more on qualitative data or information expressed as words, pictures, or particular objects without statistical processes (Neuman, 2014). The researchers describe the analysis problem best understood by exploring concepts or phenomena (Creswell and Creswell, 2018).

Based on the objectives, this study is descriptive qualitative research that aims to provide a specific description of the fulfillment of the principle of inter-nation equity in the design of the allocation of taxing rights (Amount A) in the OECD/G20 Pillar One proposal. Data collection was carried out through a literature study and document analysis to obtain a complete and valid description. First, the data are grouped with the same type and category and then complete the triangulation process between one data source and other data sources. After analyzing the data, the final process to draw conclusions and provide relevant recommendations.

\section{RESULT AND DISCUSSION}

\section{A. Overview of Taxing Rights Allocation Scheme in Amount A}

The Pillar One through the Amount A element offers a new allocation of taxing rights. The draft is intended to address the digital economy's taxation challenges, particularly taxing foreign companies that operate cross-border transactions and provide market jurisdictions with a broader share of taxes on global digital 'giants' profits. The new taxing rights draft (Amount A) will be an "overlay" on the current nexus and profit allocation rules (OECD, 2020).

The scheme in the Amount A design offers an alternative to current taxation rules, which solely rely on a physical presence (Cobham et al., 2019). Several key features in the Amount A design are entirely new and different from the current international taxation framework. The components seem like "game-changers" of international taxation rules, i.e., the revenue threshold, scoping rules, new nexus rules, and reallocating residual profit (Eden and Treidler, 2019).

Amount A administers the allocation of taxing rights to market jurisdictions through several stages and filtration. The scheme will set profits allocation through the formulation. The taxing rights for market jurisdictions are taken from a share of the residual profit calculated at the MNE groups level or group segment (OECD, 2020). The scheme and stages of allocating taxing rights will be briefly described as follows. The overview is taken from the simplified OECD/G20 BEPS Report on the Pillar One Blueprint (2020).

Step I: Determine the MNE groups covered in the Scope.

The new taxing rights allocation scheme only applies to MNE groups covered within the Scope provisions. Determination of Scope on Amount A is based on two tests, i.e., activity tests and threshold tests. The activity test determines MNE groups included in the terms that engaged in Automated Digital Services (ADS) and Consumer-facing Business (CFB). The threshold test determines the MNE groups covered in the Scope provisions, which pass the global revenue test and de minimis foreign source in-scope revenue test. The global revenue threshold is applied on the consolidated financial accounts of the MNE group, while the de minimis foreign source inscope revenue test examines revenue earned outside the domestic market. There has been no final decision regarding the quantum of this threshold.

Step II: Determine the tax base for calculating Amount A.

Determination of the tax base consists of three stages as follows (i) determining PBT (Profit Before Tax) based on the consolidated financial accounts of the MNE group, (ii) determining whether the MNE group needs to segment the amount of PBT, and (iii) applying loss carry-forward rules to take into account the losses incurred and offset them to future gains. Profit before tax is a comprehensive amount generally consists of all income and expenses of the MNE group except income tax expense. The MNE group may segment the amount of PBT if most of the income comes from activities outside the scope of ADS and CFB activities. The loss carry-forward provision is intended to ensure that Amount A is based on an appropriate net profit measure.

Step III: Apply Nexus test to determine the eligible jurisdiction for a share of Amount A

The new nexus rules will be based on indicators of a significant and sustained economic presence in the market. Significance of presence as measured by market revenue threshold adapted for the size of the economy of each jurisdiction. A nexus exists when the MNE group's revenue sourced from market jurisdictions exceeds the threshold of EUR X million in a year.

Step IV: Allocate Amount A to eligible market jurisdictions via formula

This publication is licensed under Creative Commons Attribution CC BY.

http://dx.doi.org/10.29322/IJSRP.11.07.2021.p11553

WWW.ijsrp.org 
The following step of allocating Amount A begins with determining the profitability threshold as a limit to separate routine profit from residual profit. The profitability of the MNE group (or segment) will be calculated as a percentage (\%) derived from the ratio of PBT to revenue. Residual profit is MNE group income that exceeds the profitability level. After knowing the residual profit, the next step is to determine the percentage of the residual profit to be distributed to the eligible market jurisdictions. According to the allocation guidelines, the quantum of the residual profit share is then apportioned to various eligible market jurisdictions.

Step V: Eliminate double taxation

As MNE group profits have been allocated based on the current profit allocation rules, a mechanism is needed to reconcile the new taxing rights (calculated at the group or segment level) with the current profit allocation rules (calculated at the base). This is necessary to prevent double taxation.

\section{B. Inter-nation equity in Amount A profit allocation formula}

The concept of inter-nation equity concerns the distribution of taxing rights between countries (Pistone et al., 219). Each jurisdiction tends to maximize its tax revenues to fund the provision of public goods and services. From an international perspective, each jurisdiction needs to earn a fair share of taxes on income derived from cross-border transactions (Arnold, 2016). According to Rohatgi (2005), a fair distribution of global tax revenues between countries is essential.

Concerning the distribution of taxing rights in the digital economy, thought to aspects of inter-nation equity is an essential matter (Schoen, 2019). In sequence to accomplish fairness amid nations, more thoughtful consideration of inter-nation equity is crucial when designing an international tax framework. It aims to encourage progress in the distribution of taxing rights between developed and developing economies. The allocation of taxing rights provisions is based on a nexus existence (Pistone et al., 2019).

The Amount A provisions in Pillar One are designed to serve a broader share of taxation to the market (OECD, 2020). Hence, profit allocation schemes need to take into account the principle of inter-nation equity (Rohatgi, 2005; Arnold, 2016; Pistone et al., 2019). An analysis performed on the taxing rights allocation scheme disclosed previously identified three areas closely related to inter-nation equity.

The first area is the residual profit terms. The Amount A mechanism uses a stage and formula to distribute MNE's share of group profits within the scope of the eligible jurisdictions. Eligible market jurisdictions will receive a portion (in X\%) of the residual profit. Residual income is the MNE group's income that exceeds a certain agreed level of profitability threshold (OECD, 2020). The formulation illustrated as follows:

$$
\text { Amount } \mathrm{A}=(\text { Residual Profit } \mathrm{x}[\mathrm{X} \%])
$$

or

$$
\text { Amount } \mathrm{A}=([\mathrm{PBT}-\text { Profitability Threshold }] \mathrm{x}[\mathrm{X} \%])
$$

or

$$
\text { Amount } \mathrm{A}=([\mathrm{PBT}-(\mathrm{PBT} \times \mathrm{Y} \%)] \times[\mathrm{X} \%])
$$

The second area is the threshold element to separate routine profit from residual profit entitled the profitability threshold. The Amount A allocation scheme applies a threshold to separate the residual profit from the quantum of profit before tax (PBT). This profitability threshold separates routine profits to remain under the current transfer pricing rules (OECD, 2020). The profitability will be determined by a percentage (\%) derived from Amount A's profit before tax to the income ratio.

The third area is the measure of reallocation percentage. Once the residual profit is known, Amount A then establishes a percentage to reallocate the share of the residual profit to the market jurisdiction. The quantum to be allocated is not the entire residual profit but the residual profit multiplied by a fixed percentage. Following this scheme, only a share of the residual profit of an MNE group (or segment) is reallocated to market jurisdictions (OECD, 2020). An illustration of the three areas shown in the table below.

Table 2. Profit Allocation Scheme Overview

\begin{tabular}{|c|c|c|}
\hline \multirow{2}{*}{$\begin{array}{c}\text { Profitability } \\
\text { Threshold }\end{array}$} & Reallocation Percentage & $\begin{array}{c}\text { Estimated global residual profits allocated } \\
\text { to market jurisdictions (billion USD) }\end{array}$ \\
\hline \multirow{3}{*}{$8 \%$} & $10 \%$ & 60 \\
\cline { 2 - 3 } & $20 \%$ & 120 \\
\cline { 2 - 3 } & $30 \%$ & 180 \\
\hline \multirow{2}{*}{$10 \%$} & $10 \%$ & 49 \\
\cline { 2 - 3 } & $20 \%$ & 98 \\
\hline \multirow{2}{*}{$15 \%$} & $30 \%$ & 147 \\
\cline { 2 - 3 } & $10 \%$ & 29 \\
\cline { 2 - 3 } & $20 \%$ & 58 \\
\hline
\end{tabular}




\begin{tabular}{|c|c|c|}
\hline $\begin{array}{l}\text { Profitability } \\
\text { Threshold }\end{array}$ & Reallocation Percentage & $\begin{array}{l}\text { Estimated global residual profits allocated } \\
\text { to market jurisdictions (billion USD) }\end{array}$ \\
\hline \multirow[t]{3}{*}{$20 \%$} & $10 \%$ & 17 \\
\hline & $20 \%$ & 34 \\
\hline & $30 \%$ & 51 \\
\hline \multirow[t]{3}{*}{$25 \%$} & $10 \%$ & 10 \\
\hline & $20 \%$ & 20 \\
\hline & $30 \%$ & 30 \\
\hline
\end{tabular}

Source: OECD (2020)

The following case will briefly illustrate the table above. Assume that the profitability threshold of $8 \%$ and the reallocation percentage of $10 \%$. It is estimated that USD 60 billion will be allocated to market jurisdictions. By this approach, $90 \%$ of the remaining profits of the MNE group (or segment) will still be taxed according to the current arm's length principle (ALP) profit allocation system. While the other $10 \%$ is a tax base allocated for Amount A purposes (OECD, 2020).

From the illustration above, the market jurisdiction's profit share depends on the formulation chosen in the consensus. The market jurisdiction's benefits depend on combining the profitability threshold and the percentage of reallocation agreed. A lower profitability threshold will not certainly result a significant residual profit if it is not combined with the suitable reallocation percentage. Engaging a combination is crucial to ensuring the market jurisdiction seizes a significant share of the profits. The remaining quantum profit yet should be distributed through various jurisdictions that meet the qualifications of Amount A.

The profit share that the market jurisdiction will earn depends on residual profit as the tax base. The sum of residual profit depends on the agreed profitability threshold. The sum to be distributed to market jurisdictions also depends on the reallocation percentage. These three interrelated areas are the key to the fairness of the new taxing rights allocation scheme. Indeed, any option taken must still be considered, such as the effect on compliance costs and administrative costs.

Various interests between countries play a massive role in searching for consensus on taxation of the digital economy. The proposal should be able to provide an equal level playing field between developed and developing economies. Thoughtful decisions are needed to address the taxation challenges of the digital economy. The fulfillment of inter-nation equity in the three areas above is a key in overcoming taxation challenges as well as an essential move to avoid the spread of disputes and unilateral measures. The share of profits allocated to eligible jurisdictions should reflect a proportionate mass of MNE group profits sourced from those jurisdictions. This profit allocation should provide a significant share of tax revenue to market jurisdictions where a large number of MNE group consumers reside.

\section{CONCLUSION}

The principal objective of tax policy design is to achieve the fairness of taxation. Regarding allocating taxing rights in the digital economy, considering the principle of inter-nation equity while designing allocation schemes is essential. Identifying areas within the scheme that embrace fairness is the first step to promoting inter-nation equity into the taxing rights scheme. We place three of Amount A's main areas highly relevant to encourage equity toward allocating taxing rights. These areas are under the terms of profit allocation, i.e., residual profit terms, the profitability threshold, and the reallocation percentage.

Securing those three areas in determining the sum of profit allocation will significantly contribute to fulfilling the principle of internation equity and ensuring that market jurisdictions get a significant share of profits. The significance of market jurisdiction's benefits depends on the set of profitability thresholds and the percentage of reallocation. A simple way of assessing the fulfillment of internation equity is by measuring the proportion of profits allocated to a market jurisdiction over the revenue generated from such jurisdiction. However, the subsequent study using quantitative data is required to assess the fulfillment of equity in the scheme accurately.

\section{REFERENCES}

Alm, J., Blaufus, K., Fochmann, M., Kirchler, E., Mohr, P., Olson, N. E., \& Torgler, B. (2020). Tax Policy Measures to Combat the SARS-CoV-2 Pandemic and Considerations to Improve Tax Compliance: A behavioral perspective. WU International Taxation Research Paper Series, (2020-10).

Arnold, B. J. (2016). International tax primer. Kluwer Law International BV.

Cobham, A., Faccio, T., \& FitzGerald, V. (2019). Global Inequalities in Taxing Rights: An Early Evaluation of The OECD Tax Reform Proposals. SocArXiv

Creswell, J. W., \& Creswell, J. D. (2017). Research Design: Qualitative, quantitative, and mixed methods approaches - Fifth Edition. Sage publications.

Devereux, M. P. (1996). The Economics of Tax Policy. New York: Oxford University Press. 
Devereux, M. P., Auerbach, A. J., Keen, M., \& Schön, W. (2021). Taxing Profit in A Global Economy. Oxford University Press.

Economics, O. \& Huawei. (2017). Digital Spillover: Measuring the True Impact of the Digital Economy - A Report by Huawei and Oxford Economics. United Kingdom: Oxford.

Eden, L., \& Treidler, O. (2019). Insight: Taxing the Digital Economy-Pillar One Is Not BEPS 2 (Parts I and II). Forthcoming in Tax Management International Journal (Nov. 2019). Part I published in Tax Notes Daily (Nov 8, 2019).

Geringer, S. (2021). National Digital Taxes-Lessons from Europe. South African Journal of Accounting Research, 35(1), 1-19.

Jones, B., Seabrook, S., Sciliberto, S., Jones, G., \& Sutherland, E. (2018). Taxing the Digital Economy. Tax Journal, (1389), 2.

Kobetsky, M. (2011). International Taxation of Permanent Establishments: Principles and Policy. Cambridge University Press.

Lawrence Neuman, W. (2014). Social Research Methods: Qualitative and Quantitative Approaches - Seventh Edition. London: Pearson Education Limited.

Li, J. (2015). Protecting the Tax Base in a Digital Economy. United Nations Handbook on Selected Issues in Protecting the Tax Base of Developing Countries.

Li, K., Kim, D. J., Lang, K. R., Kauffman, R. J., \& Naldi, M. (2020). How should We Understand the Digital Economy in Asia? Critical Assessment and Research Agenda. Electronic Commerce Research and Applications, 44, 101004.

OECD. (2013). Addressing Base Erosion and Profit Shifting. Paris: OECD Publishing.

OECD. (2015). Addressing the Tax Challenges of the Digital Economy, Action 1 - 2015 Final Report, OECD/G20 Base Erosion and Profit Shifting Project. Paris: OECD Publishing.

OECD. (2018). Tax Challenges Arising from Digitalisation - Interim Report 2018: Inclusive Framework on BEPS, OECD/G20 Base Erosion and Profit Shifting Project. Paris: OECD Publishing.

OECD. (2020). Tax Challenges Arising from Digitalisation - Report on Pillar One Blueprint: Inclusive Framework on BEPS, OECD/G20 Base Erosion and Profit Shifting Project. Paris: OECD Publishing.

Olbert, M., \& Spengel, C. (2019). Taxation in the Digital Economy-Recent Policy Developments and the Question of Value Creation. ZEW-Centre for European Economic Research Discussion Paper, (19-010).

Pistone, P., Roeleveld, J., Hattingh, J., Pinto Nogueira, J. F., \& West, C. (2019). Fundamentals of Taxation: An Introduction to Tax Policy, Tax Law and Tax Administration. Amsterdam: IBFD.

Rohatgi, R. (2007). Basic International Taxation Second Edition Volume I: Principles. London: Richmond Law \& Tax Ltd.

Schoen, W. (2017). Ten Questions About Why and How to Tax the Digitalized Economy. Working Paper of the Max Planck Institute for Tax Law and Public Finance No. 2017-11, 2017, pp. 1-29.

Schoen, W. (2019). One Answer to Why and How to Tax the Digitalized Economy. Intertax, 47(12).

Sukardi, I., Indonesia, R. S. M., \& Jiaqian, S. S. (2020). Taxing the Digital Economy in Indonesia. International Tax Review.

Sydänmaanlakka, L. (2021). OECD Pillar One Proposal: Fragmentation of the Profit Allocation Rules: A Level Playing Field?

Tambunan, M. R., \& Rosdiana, H. (2020). Indonesia Tax Authority Measure on Facing the Challenge in Taxing Digital Economy. The International Technology Management Review, 9(1), 1-10.

Tapscott, D. (1996). The Digital Economy: Promise and Peril In The Age of Networked Intelligence (Vol. 1). New York: McGrawHill.

Turina, A. (2020). The Progressive Policy Shift in The Debate on The International Tax Challenges of The Digital Economy: A "Pretext" For Overhaul of The International Tax Regime?. Computer Law \& Security Review, 36, 105382.

Vann, R. J. (1998). International Aspects of Income Tax. Tax Law Design and Drafting, 2, 1-89.

Yuan, S., Musibau, H. O., Genç, S. Y., Shaheen, R., Ameen, A., \& Tan, Z. (2021). Digitalization of Economy is the Key Factor Behind Fourth Industrial Revolution: How G7 Countries Are Overcoming With the Financing Issues? Technological Forecasting and Social Change, 165, 120533.

\section{AUTHORS}

First Author - Arief Hakim P. Lubis, Post-graduate Student, Universitas Indonesia, ariefhakimlubis@ gmail.com.

Second Author - Dr. Ning Rahayu, Lecturer, Universitas Indonesia, ning.rahayu @yahoo.com.

Correspondence Author - Arief Hakim P. Lubis, ariefhakimlubis@gmail.com, arief.hakim@ui.ac.id. 